\title{
Is declining malaria vector population in Africa a result of intervention measures or sampling tools inefficiency?
}

\section{Há redução dos vetores da malária na África como resultado das medidas de intervenção ou por conta de ferramentas de amostragem ineficientes?}

\author{
Eliningaya J. Kweka ${ }^{1,2 \dagger}$, Stephen Munga ${ }^{3}$, Humphrey D. Mazigo ${ }^{2}$ \\ 1. Tropical Pesticides Research Institute, Division of Livestock and Human Disease Vector Control, P.O.Box 3024, Arusha, 2. Department of Medical \\ Parasitology and Entomology, Catholic University of Health and Allied Sciences, P.O. Box 1464, Mwanza, Tanzania, 3. Centre for Global Health \\ Research, Kenya Medical Research Institute, P.O.Box 1578 Kisumu, Kenya.
}

\begin{abstract}
Recent entomological surveys have shown a declining trend of malaria vector population in sub-Saharan Africa and the observation have been associated with the scale-up and intensive use of malaria intervention measures such as insecticides treated nets and insecticide residual sprays. However, little is known on the contribution of the mosquito sampling tools inefficiency on the declining trends of malaria vector population. In this commentary paper, we explore the possibility of contribution of mosquito sampling tools' inefficiency to the observed declining trends of malaria vector population in Africa.
\end{abstract}

Keywords: Malaria. Mosquitoes. Anopheles. Africa.

\section{Resumo}

Pesquisas entomológicas recentes têm mostrado uma tendência de redução da população do vetor da malária na África sub-saariana e essa observação têm sido associado com o uso intensivo intensivo de medidas de intervenção, tais como mosquiteiros impregnados com inseticidas e borrifação com inseticidas residuais. Contudo, pouco se sabe sobre a eficiência de instrumentos de amostragem de mosquitos e a contribuição dessa ferramenta sobre as tendências de declínio da população do vetor da malária. Neste artigo, exploramos a contribuição ineficiente dos instrumentos de amostragem de mosquitos para observar uma redução da população de vetores da malária na África.

Palavras-chave: Malária. Mosquitos. Anopheles. África.

\section{Malaria vector sampling against intervention tools}

For many years, malaria vector density estimation has been carried out using indoor sampling methods for host seeking and resting vectors ${ }^{1-3}$. Little attention has been directed to the use of outdoor sampling tools especially on large scale scenarios $^{4-7}$. Various techniques used for indoor sampling of resting mosquitoes includes: Centers for Disease Control (CDC) miniature light traps (referred as gold standard method), mechanical aspirators and pyrethrum spray catch $^{3,8-13}$. These techniques have their own advantages and disadvantages and are described elsewhere ${ }^{3,8-13}$.

The intensive use of malaria intervention measures is one of the important factors which in part affect the performance of the mosquito sampling tools ${ }^{14-16}$. Use of ITNs has been linked to the reported declining in malaria vectors population ${ }^{16-18}$. However, changing of mosquito feeding/ biting behaviour from feeding indoor to feeding outdoor for avoiding the knockdown effects of ITNs also affects the performance of indoor vector trapping tools. This in turn, affects estimation of vectors collected by these techniques and thus the techniques may not give a true representation of the vector abundance but rather shows the outcomes of vector interventions implemented. Thus the declining trends of indoor resting malaria vector densities might be misinterpreted due to vector feeding and resting behavioral changes or increased exophily due to use of treated ITNs.

\section{Malaria vector decline and shift in species composition}

On the other hand, IRS programmes which uses either lambdacyhalothrin or deltamethrin has been widely advocated and used for malaria control programmes ${ }^{17,18}$. These insecticides are sprayed on the inner wall surfaces where mosquitoes rest before and after taking a blood 
meal $^{3}$. The insecticides have strong repellence and high knockdown effects on malaria vectors. Due to the repellence and knockdown effects, the major malaria vectors have changed their behaviours ${ }^{4,19}$ and they remain outdoor or immediately knocked down when they gain access to houses sprayed with IRS. Under these circumstances, light traps and pyrethrum spray catch techniques are likely to collect fewer mosquitoes indoors than before the control measures were instituted. Consequently, the lower densities of indoor malaria vector which are currently collected by the indoor mosquito sampling techniques due to the effects of malaria intervention measures cannot be easily translated as the decline of malaria vectors population.

\section{Malaria vector population decline}

In an area of high coverage with ITNs and LLINs, declining trends of malaria vectors has been observed. Larvae of An.gambiae s.s in habitats were demonstrated to decrease with increasing bed net coverage. On the other hand, when data of two species was compared over time, it was reported that An. arabiensis replaced An.gambiae $s . s$ as the dominant species ${ }^{20,21}$. One plausible reason for this incidence is, An.gambiae s.s prefers to feed and rest indoors, thus the population of this species may have decreased due to lack of human blood meal accessibility and mortality may have increased due to contact with insecticides treated nets. Similarly, findings from another area in western Kenya have also showed decreasing trends of An. arabiensis population indoors in areas with high coverage of ITN/LLINs and alternative host outdoor $^{22}$. Previous studies in western Kenya found that An. arabiensis comprised $3 \%$ of the adult An. gambiae complex sampled indoors ${ }^{23,24}$ while another study in the same area reported that An .arabiensis comprised of $10 \%{ }^{25}$. On the other hand, larval samples from the same area reported the highest proportions (37.7\%) of An. arabiensis ever recorded in the area ${ }^{22}$. The lower densities of An. arabiensis in indoor collections using CDC miniature light trap and PSC collections may not have suggested a reduction in vector densities as a result of the interventions tools but rather availability of alternative hosts' outdoors may have influenced outdoor abundance of the species ${ }^{26,27}$. This might be the source of species replacement observed by Bayoh and others in other parts of western Kenya where the coverage of the LLINs exceeded $90 \%{ }^{20}$.

Further, recent observations made in western Kenya and northern Tanzania have revealed that, traditional method of using plant repellents indoor have impacted on indoor vector densities ${ }^{28-31}$. Plants used include: Ocimum species, Lantana camara, Eucalyptus and Azadirachta indica A. Jussieu (Sapindales: Meliaceae), whether fresh, dried or smoked $^{32}$. Smoke restricts mosquitoes' house entry and increases aggression of both fed and unfed mosquitoes ${ }^{29}$. Repellent plants growing around houses have been demonstrated to deter house entry of Anopheline mosquitoes hence lower indoor collection ${ }^{33}$.

The use of Ivermectine dosages in filariasis and animal health control programmes ${ }^{34-36}$, has been observed to reduce survivorship in mosquitoes which have fed on a blood meal taken from hosts injected with a dose of Ivermectine. In that particular study, the reduction of mosquito densities in the non-intervention areas were not clearly understood however the decline was associated with the use of Ivermectine for animals and filariasis control $^{14}$. The decline of mosquito densities throughout the area could not be attributed only to the use of Ivermectine but rather when all animals were treated with dose of Ivermectine.

In massive interventions with IRS and LLINS, CDC light trap and bed nets failed to reliably assess the human biting rates in Bioko Island ${ }^{37}$. Consequently, evaluation of efficacy of other outdoor and indoor trapping systems should be of importance and priority given the scale up of intervention tools using IRS and LLINs. Currently, only a few outdoor trapping systems have been evaluated in small scale and have shown to be efficient in estimating vector abundance ${ }^{4,6,22}$. Much more focus should be given in evaluating these outdoor malaria vector trapping tools in large scale in the face of the increasing scale up of malaria intervention tools.

\section{Conclusion}

Vector density estimation in this era of massive scale up of vector control operations should be revisited with the main emphasis on the possible change in resting and feeding behaviour of mosquitoes in malaria endemic regions. 


\section{References}

1. Mboera LE. Sampling techniques for adult Afrotropical malaria vectors and their reliability in the estimation of entomological inoculation rate. Tanzan Health Res Bull 2005 Sep;7(3):117-24. PubMed PMID: 16941936.

2. Odetoyimbo JA. Preliminary investigation on the use of a light trap for sampling malaria vectors in The Gambia. Bull World Health Organ 1969 Apr;40(4):547-60. PubMed PMID: 5306720.

3. World Health Organization (CH). Manual on practical entomology in malaria. Part II [Internet]. Geneva: World Health Organization Division of Malaria and Other Parasitic Diseases; 1975 [cited 2012 Oct 2]. 191 p. Available from: http://whqlibdoc.who.int/offset/WHO_OFFSET_13_(part2).pdf

4. Govella NJ, Chaki PP, Mpangile JM, Killeen GF. Monitoring mosquitoes in urban Dar es Salaam: Evaluation of resting boxes, window exit traps, CDC light traps, Ifakara tent traps and human landing catches. Parasit Vectors. 2011 Mar;21(4):40. doi: 10.1186/1756-3305-4-40. PubMed PMID: 21418622.

5. Kweka EJ, Mahande AM. Comparative evaluation of four mosquitoes sampling methods in rice irrigation schemes of lower Moshi, northern Tanzania. Malar J. 2009 Jul 6;8:149. doi: 10.1186/1475-2875-8-149. PubMed PMID: 19580663.

6. Kweka EJ, Mwang'onde BJ, Kimaro E, Msangi S, Massenga CP, Mahande AM. A resting box for outdoor sampling of adult Anopheles arabiensis in rice irrigation schemes of lower Moshi, northern Tanzania. Malar J. 2009 Apr 25;8:82. doi: 10.1186/1475-2875-8-82. PubMed PMID: 19393098.

7. Mahande A, Mosha F, Mahande J, Kweka E. Feeding and resting behaviour of malaria vector, Anopheles arabiensis with reference to zooprophylaxis. Malar J. 2007 Jul 30;6:100. PubMed PMID: 17663787.

8. Dinesh DS, Das P, Picado A, Davies C, Speybroeck N, Boelaert M, Coosemans $M$. The efficacy of indoor CDC light traps for collecting the sandfly Phlebotomus argentipes, vector of Leishmania donovani. Med Vet Entomol. 2008 Jun; 22(2):120-3. doi: 10.1111/j.13652915.2008.00724.x. PubMed PMID: 18498610.

9. Gunasekaran K, Jambulingam P, Sadanandane C, Sahu SS, Das PK. Reliability of light trap sampling for Anopheles fluviatilis, a vector of malaria. Acta Trop. 1994 Oct;58(1): 1-11. PubMed PMID: 7863849.

10. Mboera LE, Kihonda J, Braks MA, Knols BG. Short report: Influence of centers for disease control light trap position, relative to a human-baited bed net, on catches of Anopheles gambiae and Culex quinquefasciatus in Tanzania. Am J Trop Med Hyg. 1998 Oct;59(4):595-6. PubMed PMID: 9790436.

11. Sadanandane $C$, Jambulingam $P$, Subramanian S. Role of modified CDC miniature light-traps as an alternative method for sampling adult anophelines (Diptera: Culicidae) in the National Mosquito Surveillance Programme in India. Bull Entomol Res. 2004 Feb;94(1): 55-63. PubMed PMID: 14972050.

12. Singh N, Mishra AK. Efficacy of light-traps in sampling malaria vectors in different ecological zones in central India. Southeast Asian J Trop Med Public Health. 1997 Mar; 28(1):196-202. PubMed PMID: 9322305.

13. van den Bijllaardt W, ter Braak R, Shekalaghe S, Otieno S, Mahande A, Sauerwein R, Takken W, Bousema T. The suitability of clay pots for indoor sampling of mosquitoes in an arid area in northern Tanzania. Acta Trop. 2009 Aug; 111(2):197-9. doi: 10.1016/j.actatropica.2009.04.003. Epub 2009 Apr 11. PubMed PMID: 19524083.

14. Meyrowitsch DW, Pedersen EM, Alifrangis M, Scheike TH, Malecela MN, Magesa SM, Derua YA, Rwegoshora RT, Michael E, Simonsen PE. Is the current decline in malaria burden in sub-Saharan Africa due to a decrease in vector population? Malar J. 2011 Jul 13; 10:188. doi: 10.1186/1475-2875-10-188. PubMed PMID: 21752273.
15. Ashton RA, Kyabayinze DJ, Opio T, Auma A, Edwards T, Matwale G, Onapa A, Brooker S, Kolaczinski JH. The impact of mass drug administration and long-lasting insecticidal net distribution on Wuchereria bancrofti infection in humans and mosquitoes: an observational study in northern Uganda. Parasit Vectors. $2011 \mathrm{Jul}$ 15;4:134. doi: 10.1186/1756-3305-4-134. PubMed PMID: 21756371.

16. Mutuku FM, King $\mathrm{CH}$, Mungai $\mathrm{P}$, Mbogo C, Mwangangi J, Muchiri EM, Walker ED, Kitron U. Impact of insecticide-treated bed nets on malaria transmission indices on the south coast of Kenya. Malar J. 2011 Dec 13;10:356. doi: 10.1186/1475-2875-10-356. PubMed PMID: 22165904

17. Raghavendra K, Ghosh SK, Eapen A, Tiwari SN, Satyanarayan TS, Ravindran J, Sreehari U, Dash AP. Field evaluation of lambdacyhalothrin (ICON 10 CS) indoor residual spraying against Anopheles culicifacies in India. J Vector Borne Dis. 2011 Mar;48(1): 18-26. Erratum in: J Vector Borne Dis. 2011 Jun;48(2):following 123. PubMed PMID: 21406733.

18. Tobgay T, Torres CE, Na-Bangchang K. Malaria prevention and control in Bhutan: successes and challenges. Acta Trop. 2011 Mar;117(3):2258. doi: 10.1016/j.actatropica.2010.11.008. Epub 2010 Nov 27. PubMed PMID: 21114957.

19. Govella NJ, Ferguson H. Why Use of Interventions Targeting Outdoor Biting Mosquitoes will be Necessary to Achieve Malaria Elimination. Frontiers in physiol. 2012;3:199. doi: 10.3389/fphys.2012.00199. Epub 2012 Jun 12. PubMed PMID: 22701435.

20. Bayoh MN, Mathias D, Odiere M, Mutuku F, Kamau L, Gimnig J, Vulule J, Hawley W, Hamel M, Walker E. Anopheles gambiae: historical population decline associated with regional distribution of insecticidetreated bed nets in western Nyanza Province, Kenya. Malar J. 2010 Feb 26;9:62. doi: 10.1186/1475-2875-9-62. PubMed PMID: 20187956.

21. Kitau J, Oxborough RM, Tungu PK, Matowo J, Malima RC, Magesa SM, Bruce J, Mosha FW, Rowland MW. Species shifts in the Anopheles gambiae complex: do LLINs successfully control Anopheles arabiensis? PLoS One. 2012;7(3):e31481. doi: 10.1371/journal. pone.0031481. Epub 2012 Mar 16. PubMed PMID: 22438864.

22. Kweka EJ, Zhou G, Lee MC, Gilbreath TM, 3rd, Mosha F, Munga S, Githeko AK, Yan G. Evaluation of two methods of estimating larval habitat productivity in western Kenya highlands. Parasit Vectors. 2011 Jun 17;4:110. doi: 10.1186/1756-3305-4-110. PubMed PMID: 21682875.

23. Fillinger $U$, Ndenga $B$, Githeko A, Lindsay SW. Integrated malaria vector control with microbial larvicides and insecticide-treated nets in western Kenya: a controlled trial. Bull World Health Organ. 2009 Sep;87(9):655-65. PubMed PMID: 19784445

24. Munga S, Minakawa N, Zhou G, Mushinzimana E, Barrack OO, Githeko AK, Yan G. Association between land cover and habitat productivity of malaria vectors in western Kenyan highlands. Am J Trop Med Hyg. 2006 Jan;74(1):69-75. PubMed PMID: 16407348.

25. Wamae PM, Githeko AK, Menya DM, Takken W. Shading by napier grass reduces malaria vector larvae in natural habitats in Western Kenya highlands. Ecohealth. 2010 Dec;7(4):485-97. doi: 10.1007/ s10393-010-0321-2. Epub 2010 Jul 3. PubMed PMID: 20602147.

26. Coetzee M, Craig M, le Sueur D. Distribution of African malaria mosquitoes belonging to the Anopheles gambiae complex. Parasitol. Today. 2000 Feb;16(2):74-7. Review. PubMed PMID: 10652493.

27. Gillies TM, Coetzee M. Supplement of the Anopheles of Africa South of Sahara (Afrotropical Region). Volume 55: Johannesburg, The South African Institute for Medical Research; 1987. 
28. Kweka EJ, Mosha F, Lowassa A, Mahande AM, Kitau J, Matowo J, Mahande MJ, Massenga CP, Tenu F, Feston E, Lyatuu EE, Mboya MA, Mndeme R, Chuwa G, Temu EA. Ethnobotanical study of some of mosquito repellent plants in north-eastern Tanzania. Malar J. 2008 Aug 7;7:152. doi: 10.1186/1475-2875-7-152. PubMed PMID:18687119.

29. Kweka EJ, Mosha FW, Lowassa A, Mahande AM, Mahande MJ, Massenga CP, Tenu F, Lyatuu EE, Mboya MA, Temu EA. Longitudinal evaluation of Ocimum and other plants effects on the feeding behavioral response of mosquitoes (Diptera: Culicidae) in the field in Tanzania. Parasit Vectors. 2008 Oct 22;1(1):42. doi: 10.1186/17563305-1-42. PubMed PMID: 18945343.

30. Seyoum A, Kabiru EW, Lwande W, Killeen GF, Hassanali A, Knols BG. Repellency of live potted plants against Anopheles gambiae from human baits in semi-field experimental huts. Am J Trop Med Hyg. 2002 Aug;67(2):191-5. PubMed PMID: 12389946.

31. Seyoum A, Palsson K, Kung'a S, Kabiru EW, Lwande W, Killeen GF, Hassanali A, Knols BG. Traditional use of mosquito-repellent plants in western Kenya and their evaluation in semi-field experimental huts against Anopheles gambiae: ethnobotanical studies and application by thermal expulsion and direct burning. Trans R Soc Trop Med Hyg. 2002 May-Jun;96(3):225-31. PubMed PMID: 12174767.

32. Dube FF, Tadesse K, Birgersson G, Seyoum E, Tekie H, Ignell R, Hill $S R$. Fresh, dried or smoked? repellent properties of volatiles emitted from ethnomedicinal plant leaves against malaria and yellow fever vectors in Ethiopia. Malar J. 2011 Dec 19;10:375. doi: 10.1186/14752875-10-375. PubMed PMID: 22182798.
33. Mng'ong'o FC, Sambali JJ, Sabas E, Rubanga J, Magoma J, Ntamatungiro AJ, Turner EL, Nyogea D, Ensink JHJ, Moore SJ. Repellent plants provide affordable natural screening to prevent mosquito house entry in tropical rural settings-results from a pilot efficacy study. PLoS One. 2011;6(10):e25927. doi: 10.1371/journal. pone.0025927. Epub 2011 Oct 12. PubMed PMID: 22022471.

34. Hovette P, Laroche R, Verrot D, Molinier S, Touze JE. [Medical treatment of lymphatic filariasis]. Med Trop (Mars). 1991 JanMar;51(1):87-90. French. PubMed PMID: 2072855.

35. Richards F, Jr., Gonzales-Peralta C, Jallah E, Miri E. Community-based ivermectin distributors: onchocerciasis control at the village level in Plateau State, Nigeria. Acta Trop. 1996 Apr;61(2):137-44. PubMed PMID: 8740891.

36. Richards FO, Eigege A, Miri ES, Kal A, Umaru J, Pam D, Rakers LJ, Sambo Y, Danboyi J, Ibrahim B, Adelamo SE, Ogah G, Goshit D, Oyenekan OK, Mathieu E, Withers PC, Saka YA, Jiya J, Hopkins DR. Epidemiological and entomological evaluations after six years or more of mass drug administration for lymphatic filariasis elimination in Nigeria. PLoS NegI Trop Dis. 2011 Oct;5(10):e1346. PubMed PMID: 22022627.

37. Overgaard HJ, Saebo S, Reddy MR, Reddy VP, Abaga S, Matias A, Slotman MA. Light traps fail to estimate reliable malaria mosquito biting rates on Bioko Island, Equatorial Guinea. Malar J. 2012 Feb 24;11(1):56. doi: 10.1186/1475-2875-11-56. PubMed PMID: 22364588. 